\title{
UVA irradiation of BrU-substituted DNA in the presence of Hoechst 33258
}

\section{$\operatorname{AUTHOR}(\mathrm{S})$ :}

Saha, Abhijit; Kizaki, Seiichiro; Han, Ji Hoon; Yu, Zutao; Sugiyama, Hiroshi

\section{CITATION:}

Saha, Abhijit ...[et al]. UVA irradiation of BrU-substituted DNA in the presence of Hoechst 33258. Bioorganic and Medicinal Chemistry 2018, 26(1): 37-40

\section{ISSUE DATE:}

2018-01-01

URL:

http://hdl.handle.net/2433/230867

\section{RIGHT:}

(c) 2018. This manuscript version is made available under the CC-BY-NC-ND 4.0 license

http://creativecommons.org/licenses/by-nc-nd/4.0/; The full-text file will be made open to the public on 1 January 2020 in accordance with publisher's 'Terms and Conditions for Self-Archiving'.; この論文は出版社版でありません。引用の際 には出版社版をご確認ご利用ください。; This is not the published version. Please cite only the published version. 


\section{Graphical Abstract}

To create your abstract, type over the instructions in the template box below.

Fonts or abstract dimensions should not be changed or altered.

UVA irradiation of ${ }^{\mathrm{Br}} \mathrm{U}$-substituted DNA in

Leave this area blank for abstract info.

the presence of Hoechst 33258 Abhijit Saha,

Seiichiro Kizaki, Ji Hoon Han, Zutao Yu, Hiroshi

Sugiyama*

Department of Science, Graduate School of Science, Kyoto University, Sakyo, Kyoto 606-8501 (Japan)

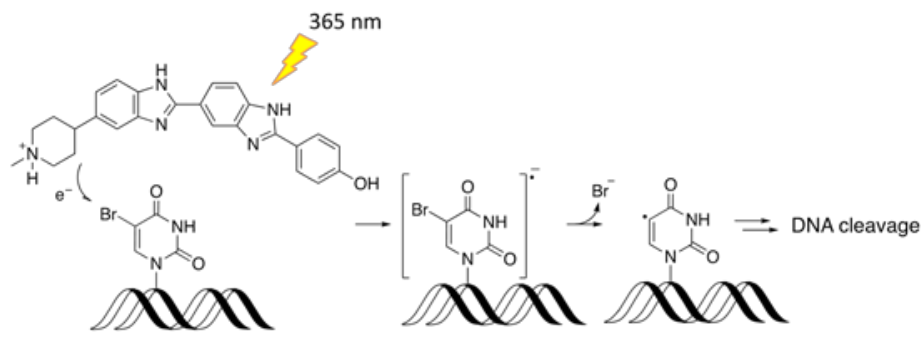




\title{
Bioorganic \& Medicinal Chemistry \\ journal homepage: www.elsevier.com
}

\section{UVA irradiation of ${ }^{\mathrm{B}} \mathrm{U}$-substituted DNA in the presence of Hoechst 33258}

\author{
Abhijit Saha ${ }^{\mathrm{a},}$, Seiichiro Kizaki ${ }^{\mathrm{a},}$, Ji Hoon $\operatorname{Han}^{\mathrm{a}}$, Zutao $\mathrm{Yu}^{\mathrm{a}}$ and Hiroshi Sugiyama ${ }^{\mathrm{a}, \mathrm{b}^{*}}$ \\ ${ }^{a}$ Department of Science, Graduate School of Science, Kyoto University, Sakyo, Kyoto 606-8501 (Japan) \\ ${ }^{b}$ Institute for Integrated Cell-Material Sciences (iCeMS), Kyoto University, Yoshida Ushinomiya-cho, Sakyo, Kyoto 606-8502 (Japan) \\ $\S$ These authors contributed equally to this work
}

\section{ARTICLE INFO}

\section{ABSTRACT}

Article history:

Received

Received in revised form

Accepted

Available online

Keywords:

Keyword_1 Micro-irradiation

Keyword_2 Electron transfer

Keyword_3 5-bromouracil

Keyword_4 DNA photoreaction

Keyword_5 Nucleosome

\begin{abstract}
Given that our knowledge of DNA repair is limited because of the complexity of the DNA system, a technique called UVA micro-irradiation has been developed that can be used to visualize the recruitment of DNA repair proteins at double-strand break (DSB) sites. Interestingly, Hoechst 33258 was used under micro-irradiation to sensitize 5-bromouracil ( ${ }^{\mathrm{Br}} \mathrm{U}$ )labelled DNA, causing efficient DSBs. However, the molecular basis of DSB formation under UVA micro-irradiation remains unknown. Herein, we investigated the mechanism of DSB formation under UVA micro-irradiation conditions. Our results suggest that the generation of a uracil-5-yl radical through electron transfer from Hoechst 33258 to ${ }^{\mathrm{Br}} \mathrm{U}$ caused DNA cleavage preferentially at self-complementary ${ }^{5}$ '- $\mathrm{AA}^{\mathrm{Br}} \mathrm{U}^{\mathrm{Br}} \mathrm{U}-3$ ' sequences to induce $\mathrm{DSB}$. We also investigated the DNA cleavage in the context of the nucleosome to gain a better understanding of UVA micro-irradiation in a cell-like model. We found that DNA cleavage occurred in both core and linker DNA regions although its efficiency reduced in core DNA.
\end{abstract}

2009 Elsevier Ltd. All rights reserved.

*This is an author version based on a template provided by Elsevier

\section{Introduction}

Ionizing radiation causes double-strand breaks (DSBs) in DNA, leading to severe damage to chromosomes in cells. Nuclear proteins accumulate at DNA-damaged sites to execute DNA repairing functions. ${ }^{1-9}$ In the field of molecular cell biology, the behavior of DNA repair proteins induced by DSB formation has been studied extensively. However, our understanding of the repair mechanism of DNA remains limited because of the complexity of the DNA repair process; many of the proteins involved in DNA repair remain unidentified. Recently, a sophisticated technique called UVA micro-irradiation was developed to provoke DSBs in living cells (Fig. 1). In this approach, nuclear DNA is labelled with the thymidine analogue 5-bromodeoxyuridine $\left({ }^{\mathrm{Br}} \mathrm{U}\right)$, and the DNA is stained with Hoechst 33258; after UVA laser (365 nm) exposure, singlestrand breaks and DSBs are produced. ${ }^{10-12}$ By using this technique, it was revealed that DNA repair proteins, Rad51 and hMre11-hRad50 complex, assemble in discrete nuclear loci as part of the cellular response to DNA damage. ${ }^{13}$ These studies established the potential of this technique in the field of experimental cell research and radiation biology and led to a better understanding of the DNA repair mechanism.

In this study, we investigated the photoirradiation of ${ }^{\mathrm{B}} \mathrm{U}-$ substituted DNA fragments in the presence of Hoechst 33258. We also investigated the photoirradiation of ${ }^{\mathrm{B}} \mathrm{U}$-substituted DNA fragments in the context of the nucleosome to gain a better understanding of nucleosome to gain a better understanding of UVA micro-irradiation in a cell-like model.
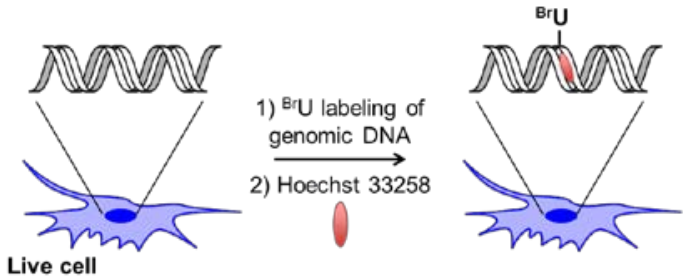

Live cell

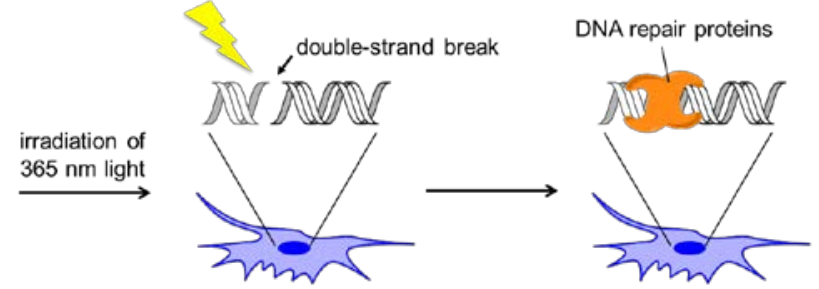

Figure 1. Schematic representation of the UVA micro-irradiation technique, which requires labelling of genomic DNA with $\mathrm{d}^{\mathrm{B}} \mathrm{UTP}$ followed by sensitization of ${ }^{\mathrm{B}} \mathrm{U}$-labelled DNA with Hoechst 33258. 


\section{Material and Methods}

\subsection{General}

Hoechst 33258 and DAPI were purchased from Sigma Aldrich (St. Louis, MO, USA) DB2120 and DB2277 were kindly provided by Prof. David Boykin and Prof. W. David Wilson (Georgia State University, USA).

\subsection{Preparation of ${ }^{\mathrm{Br}} \mathrm{U}$-labelled DNA}

In this study, we have used two DNA fragments: 298 bp DNA1 and 382 bp DNA2. These two DNAs were amplified by PCR. pUC18 plasmid and pGEM-3z/601 plasmid were used as PCR templates for DNA1 and DNA2, respectively. Primers used for DNA1 amplification; forward primer: 5'dGCAGGTCGACTCTAGAGGAT-3', reverse primer: 5'dGAGTCAGTGAGCGAGGAAG-3'. Primers used for DNA2 amplification; forward 5rimer: dTAATACGACTCACTATAGGG-3', reverse primer: 5'dATTTAGGTGACACTATAG-3'. For the analysis of top strand, 5'-Texas-Red-labeled forward primer was used, while for the analysis of bottom strand, 5'-Texas-Red-labeled reverse primer was used. All primers were purchased from Sigma Aldrich.

\subsection{Polymerase chain reaction}

Master mix for PCR reaction contain: $20 \mu \mathrm{L}$ of $10 \times$ buffer (500 $\mathrm{mM} \mathrm{KCl}, 100 \mathrm{mM}$ Tris-HCl (pH 8.3), $25 \mathrm{mM} \mathrm{MgCl}_{2}$ ), $20 \mu \mathrm{L}$ of each $2 \mathrm{mM}$ dATP, dGTP, dCTP, and $\mathrm{d}^{\mathrm{B}} \mathrm{UTP}, 6 \mu \mathrm{L}$ of each 10 $\mu \mathrm{M}$ forward and reverse primers, $2 \mu \mathrm{L}$ of $10 \mathrm{U}$ Taq DNA polymerase, $50 \mathrm{ng}$ of DNA template, and Milli-Q water to total volume of $200 \mu \mathrm{L}$. PCR was performed with iCycler (BioRad, Hercules, CA, US) in the following condition: $95{ }^{\circ} \mathrm{C}$ for $2 \mathrm{~min}$; 30 cycles of a) $95^{\circ} \mathrm{C}$ for $20 \mathrm{sec}$, b) $52^{\circ} \mathrm{C}$ for $30 \mathrm{sec}$, c) $68^{\circ} \mathrm{C}$ for $30 \mathrm{sec}$; finally $68^{\circ} \mathrm{C}$ for $7 \mathrm{~min}$. PCR products were purified with GenElute ${ }^{\mathrm{TM}}$ PCR Clean-Up Kit (Sigma Aldrich) and confirmed by $2 \%$ agarose gel electrophoresis, quantified by Nano Drop 1000 (Thermo Fisher Scientific, Waltham, MA, USA).

\subsection{Nucleosome Reconstitution using 601 sequence}

Texas-Red-labeled DNA (200 nM) and recombinant human histone octamer (EpiCypher, Davis Dr, Durham, NC, USA) (300 $\mathrm{nM}$ ) were mixed in $2 \mathrm{M} \mathrm{NaCl}$ and $20 \mathrm{mM}$ HEPES-KOH (pH 7.5) (total volume $50 \mu \mathrm{L}$ ), and placed in Oscillatory Cup (MWCO: 8000) (COSMO BIO, Tokyo, Japan). The dialysis tube was immersed into $500 \mathrm{~mL}$ of $2 \mathrm{M} \mathrm{NaCl}$ and $20 \mathrm{mM}$ HEPES $\mathrm{KOH}$ (pH 7.5) for 2 hours at $4{ }^{\circ} \mathrm{C}$, followed by $1.5 \mathrm{M} \mathrm{NaCl}$ (overnight), $1.0 \mathrm{M} \mathrm{NaCl}$ (8 hours), $0.75 \mathrm{M} \mathrm{NaCl}$ (overnight), and $0 \mathrm{M} \mathrm{NaCl}$ (8 hours) (each contains $20 \mathrm{mM}$ HEPES KOH (pH 7.5)). After dialysis, the sample was collected from the tube and stored at $4{ }^{\circ} \mathrm{C}$ until use.

\subsection{Irradiation set up}

LED light (model ZUVC30H, OMRON, Kyoto, Japan) with 300 $\mathrm{mW}$ at $365 \mathrm{~nm}$ was used for irradiation. The irradiation was performed at $0{ }^{\circ} \mathrm{C}$ by keeping the sample $(13 \mu \mathrm{L})$ in the cap of $1.5 \mathrm{~mL}$ Eppendorf Tube which was placed on a metal plate cooled with ice.

\subsection{Photoreaction}

Photoreaction was performed in $10 \mathrm{nM}{ }^{\mathrm{Br}} \mathrm{U}$-substituted DNA, 10 $\mathrm{mM}$ sodium cacodylate ( $\mathrm{pH} 7.0$ ), $500 \mathrm{mM}$ isopropanol, and 30 nM Hoechst 33258 (total volume: $13 \mu \mathrm{L}$ ). After irradiation, the reaction mixture was treated with 1.25 unit of UDG (Takara, Kusatsu, Japan) and incubated at $37{ }^{\circ} \mathrm{C}$ for $1 \mathrm{~h}$. The reaction mixture was dried up and $6 \mu \mathrm{L}$ of gel loading dye was added, followed by heat treatment at $95{ }^{\circ} \mathrm{C}$ for $10 \mathrm{~min}$. Then, all of the sample was used for slab gel sequencing.

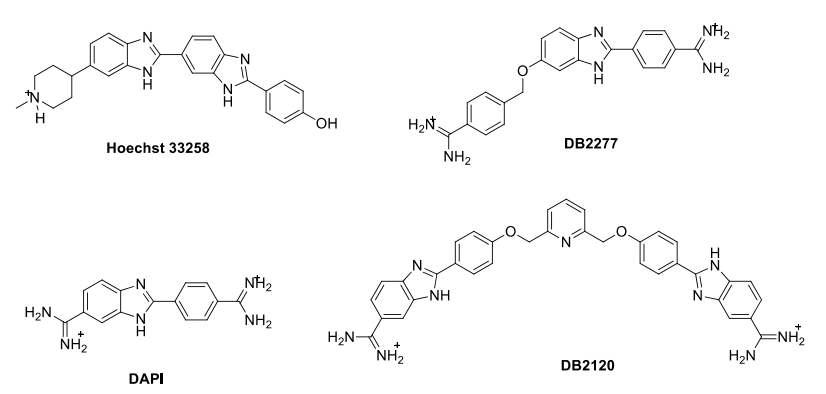

Chart 1. Chemical compounds known as DNA minor groove binder used in this study.

\section{Results and Discussions}

\subsection{Photoreaction on ${ }^{B r} U$ labeled DNA}

To gain insight into Hoechst 33258-induced DNA damage under UVA micro-irradiation, we constructed the DNA1 (298 bp) fragment, in which all the thymine residues were replaced with ${ }^{\mathrm{B}} \mathrm{U}$, by performing PCR using $\mathrm{d}^{\mathrm{B}} \mathrm{UTP}$ instead of dTTP. DNA1 was then irradiated with $365 \mathrm{~nm}$ UVA light in the presence of minor-groove-binding Hoechst 33258 and $500 \mathrm{mM}$ isopropanol (Chart. 1) ${ }^{14,15}$ for $0-4$ seconds. Under these conditions, the presumable uracil-5-yl radical generated upon capturing an electron from the dye abstracts hydrogen from the isopropanol to provide the uracil residue almost quantitatively. ${ }^{16,17}$ The sites containing the uracil residues were then cleaved by uracil glycosylase and heat treatment, and the cleavage sites were subsequently identified by slab gel sequencing. Isopropanol or THF act as an $\mathrm{H}$-atom donor under in vitro condition, which can trap the reactive radical species. ${ }^{16}$ It is also known that without the use of H-atom donor (THF or isopropanol) uracil-5-yl radical can cleave the DNA by abstracting an $\mathrm{H}$-atom from the $\mathrm{C1}^{\prime}$ position of nearest sugar moiety to produce easily cleavable 2deoxyribonolactone. Another, simultaneous $\mathrm{H}$-atom abstraction is also known from $\mathrm{C} 2^{\prime} \alpha$ position of the sugar to produce alkali labile erythrose containing site. ${ }^{18}$ As a result, the total DNA cleavage under this condition is lower. But practically, in vivo system of Hoechst induced DNA damage might consider the generation of labile 2-deoxyribonolactone instead of uracil residues prior to DNA damage. The use of isopropanol followed by UDG enzymatic digestion in the present system is only to produce one photoproduct thus making the DNA damage more visible in the in vitro system. We analyzed DNA cleavage sites for both top and bottom strands of DNA1 by using two differently labelled DNAs in which either the top or the bottom strand of DNA1 was labelled with TexasRed. As a result, several distinct DNA cleavage bands were observed on the gel (Fig. 2(a)). Importantly, DNA cleavage did not occur in the absence of Hoechst 33258, suggesting that photo-induced electron transfer from Hoechst 33258 to ${ }^{\mathrm{B}} \mathrm{U}$ residues is indispensable for uracil-2yl radical formation, as reported previously. ${ }^{18,19}$ The mapping of DNA cleavage sites on DNA1 is shown in Fig. 2(b). We detected DNA cleavage at Sites 1, 3, 4, 5, 6, and 7 (Supplementary Table 1). Among them, Sites $1,3,4$, and 5 correspond to selfcomplementary $5^{\prime}-\mathrm{AA}^{\mathrm{Br}} \mathrm{U}^{\mathrm{Br}} \mathrm{U}-3^{\prime}$ sequences, with high intensity. Several DNA cleavages were also observed in other AT-rich sequences, such as Sites 10,11 , and 12 . In addition to AT-rich sequences, other DNA cleavage sites (Sites 2, 8, 9, 13, and 14) contained a mix of GC- and AT-rich sequences. It was reported 
that Hoechst 33258 preferentially binds to AT-rich sequences (especially at $5^{\prime}$-AATT-3' sequence). ${ }^{15}$ Therefore, this result is consistent with the conclusion that electron transfer occurred from bound Hoechst 33258 to ${ }^{\mathrm{B} r} \mathrm{U}$ in the $5^{\prime}-\mathrm{AA}^{\mathrm{Br}} \mathrm{U}^{\mathrm{B} r} \mathrm{U}-3^{\prime}$ sequence to produce uracil-5-yl radical in this sequence. In cell, it is thought that the formed uracil-5-yl radical abstracts C1' hydrogen of deoxyribose from the neighboring 5'-side nucleotide to produce 2'-deoxyribonolactone, which can cause DNA cleavage by following $\beta$ - and $\delta$-eliminations. ${ }^{20}$ Given that $5^{\prime}$ $A A^{B r} U^{B r} U-3^{\prime}$ is a self-complementary sequence, it is thought that DNA cleavages at both strands leads to DSB formation.

To examine whether other DNA-binding ligands can cause DNA cleavage, we irradiated ${ }^{B}$ U-substituted DNA with other fluorescent chromosomal-staining agents: DAPI, DB2277, and DB2120 (Chart. 1) with $365 \mathrm{~nm}$ irradiation. DAPI is a DNA minor-groove-binding ligand that is normally used for fluorescence imaging. This dye also preferentially recognizes the 5'-AATT-3' sequence. ${ }^{16}$ DB2277 recognizes a single $G$ in sequences such as 5'-AAGTT-3' through an aza-benzimidazole group and DB2120, a bis-benzimidazole can recognize either A4GT4 or A4T4 sequences. ${ }^{21,22}$ Interestingly, although the three compounds have similar absorption maxima to that of Hoechst 33258 (са. $350 \mathrm{~nm}$ ), slab gel sequencing results showed that these compounds failed to cause any strand cleavage in ${ }^{\mathrm{Br}} \mathrm{U}-$ substituted DNA (Supplementary Fig. 1, 2). It is thought that compared with these three compounds, Hoechst 33258 more easily donates electron into ${ }^{\mathrm{B}} \mathrm{U}$ by photo-excitation.

\subsection{Photoreaction in Nucleosome structure}

We wondered whether such photoinduced DNA cleavage happens on a nucleosome structure, given that DNA inside a eukaryotic cell is intimately associated with proteins to form the nucleosome; that is, the DNA is wrapped around a histone octamer, which is composed of pairs of H2A, H2B, H3, and $\mathrm{H} 4 .^{23,24}$ Nucleosomes are assembled into higher-order structures, so that genomic DNA can fit into the nucleus. Therefore, we reconstituted a mononucleosome by using ${ }^{\mathrm{B}} \mathrm{U}$-substituted Widom 601-nucleosome-positioning-sequence-containing 382 bp DNA (DNA2) (Supplementary Fig. 3). ${ }^{24}$ After preparation of the reconstituted nucleosome, the ${ }^{\mathrm{Br}} \mathrm{U}$-substituted nucleosome was irradiated with Hoechst 33258 and the sites of formation of the uracil-5-yl radical were detected as described previously. At Site $3\left(5^{\prime}-\mathrm{AA}^{\mathrm{Br}} \mathrm{U}^{\mathrm{Br}} \mathrm{U}-3^{\prime}\right.$ sequence), DNA cleavage was significantly reduced on core DNA (Fig. 3, Supplementary Fig. 4). Although it is reported that Hoechst 33258 can bind to nucleosomal DNA which face both toward and away from the histone core without affecting the nucleosome structure, ${ }^{25}$ our result suggests that the binding of Hoechst 33258 to core DNA is weaker than that of Hoechst 33258 to linker DNA. At Site 2 and Site 4, the efficiency of DNA cleavage was almost same between free DNA and nucleosomal DNA. Its reason seems to be that at both Site 2 and Site 4 the nucleosomal DNA highly fluctuates to enable readily access of Hoechst 33258 to those sites. Previous reports also suggest undisturbed access of small compound and protein to the edges of core DNA. ${ }^{26,27}$

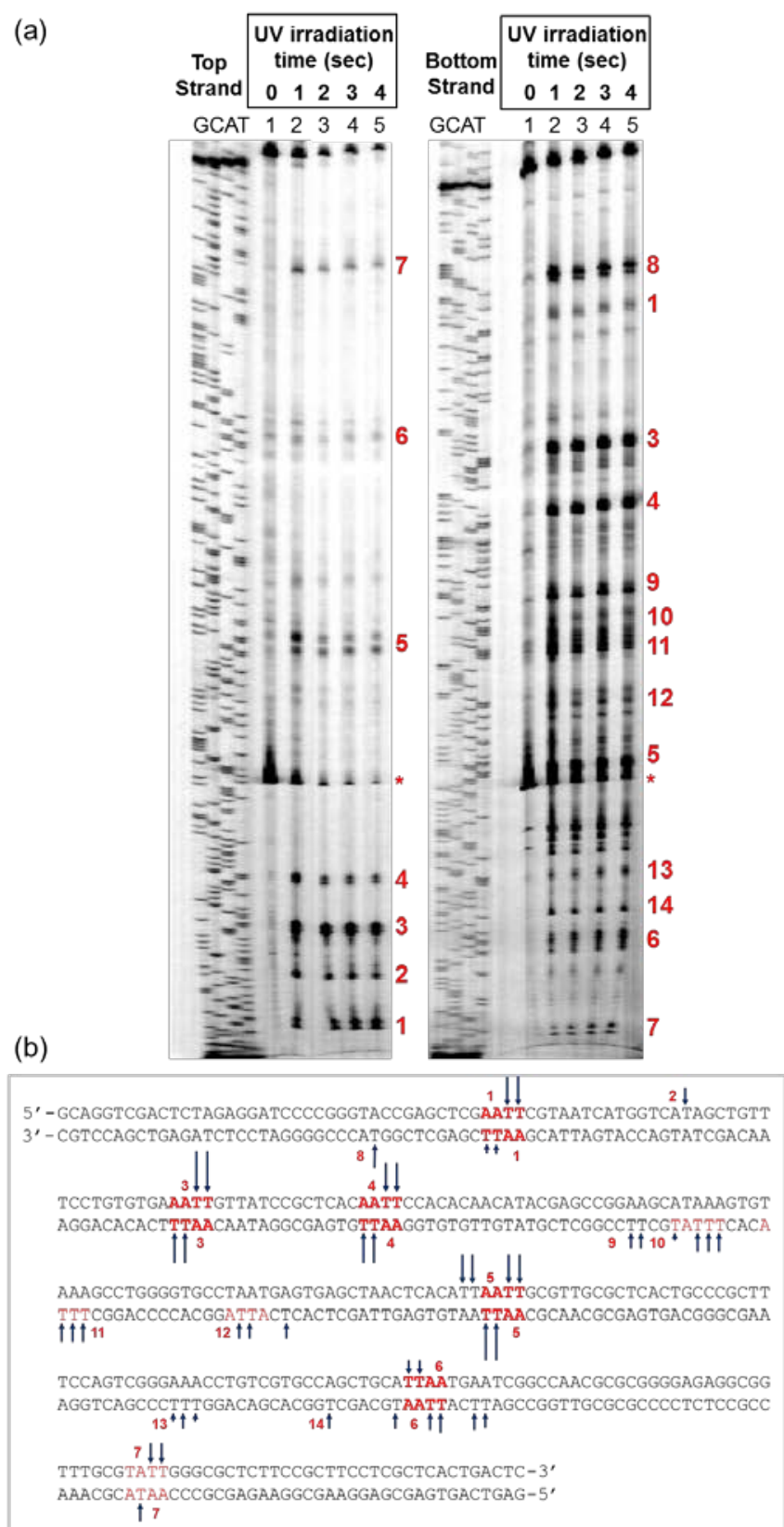

Figure 2. (a) Analysis of DNA1 fragment by using $6 \%$ denaturing gel electrophoresis. The DNA cleavage sites are marked from 1 to 14 in both strands. The band marked * derives from secondary structure of the DNA. (b) Mapping of DNA cleavage sites after photoreaction of DNA1 fragment (all Ts were replaced with ${ }^{\mathrm{B}} \mathrm{Us}$ ). The cleavage sites are indicated by numbers (from 1 to 14). 
(a)

\section{)}

sequence (pGEM3Z-601)

PCR』 dATP, dGTP, dCTP, dBrUTP

\begin{tabular}{ccc} 
& $382 \mathrm{bp}$ \\
\hline \multirow{2}{*}{601 sequence (146 bp) } & $111 \mathrm{bp}$
\end{tabular}

reconstitution histone octamer

nucleosome

(c)

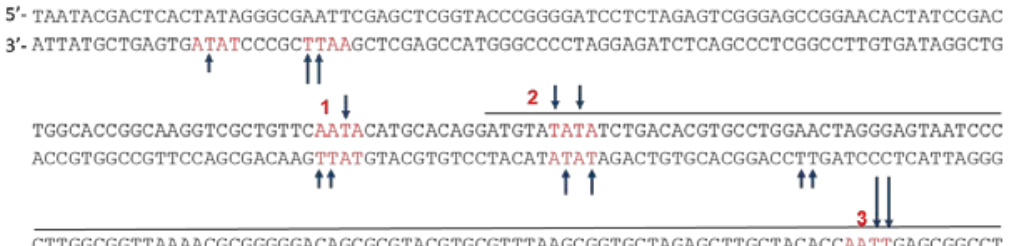

CTTGGCGGTTAAAACGCGGGGGACAGCGCGTACGTGCGTTTAAGCGGTGCTAGAGCTTGCTACACCAATTGAGCGGCCT GAACCGCCAATTTTGCGCCCCCTGTCGCGCATGCACGCAAATTCGCCACGATCTCGAACGATGTGGTTAACTCGCCGGA

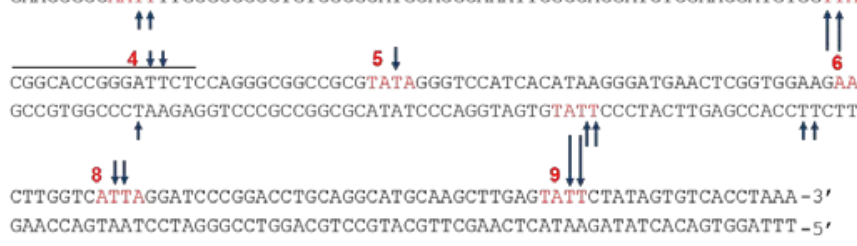

(d)

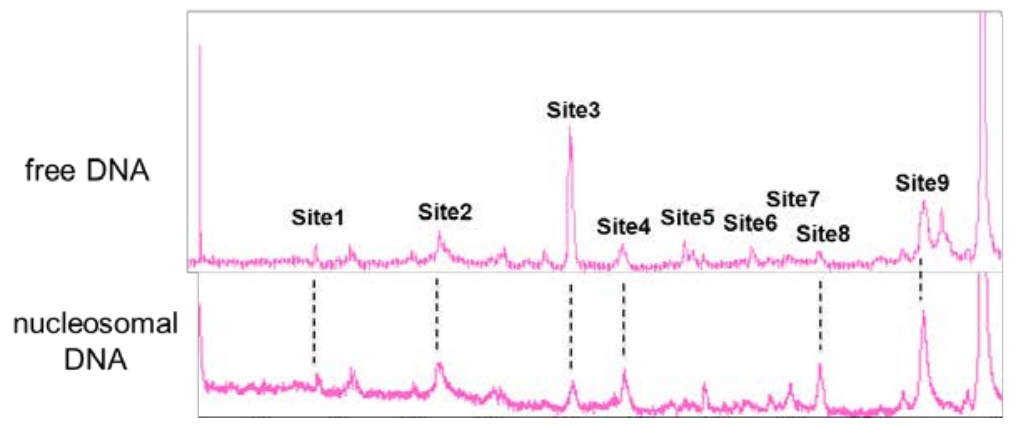

(b)

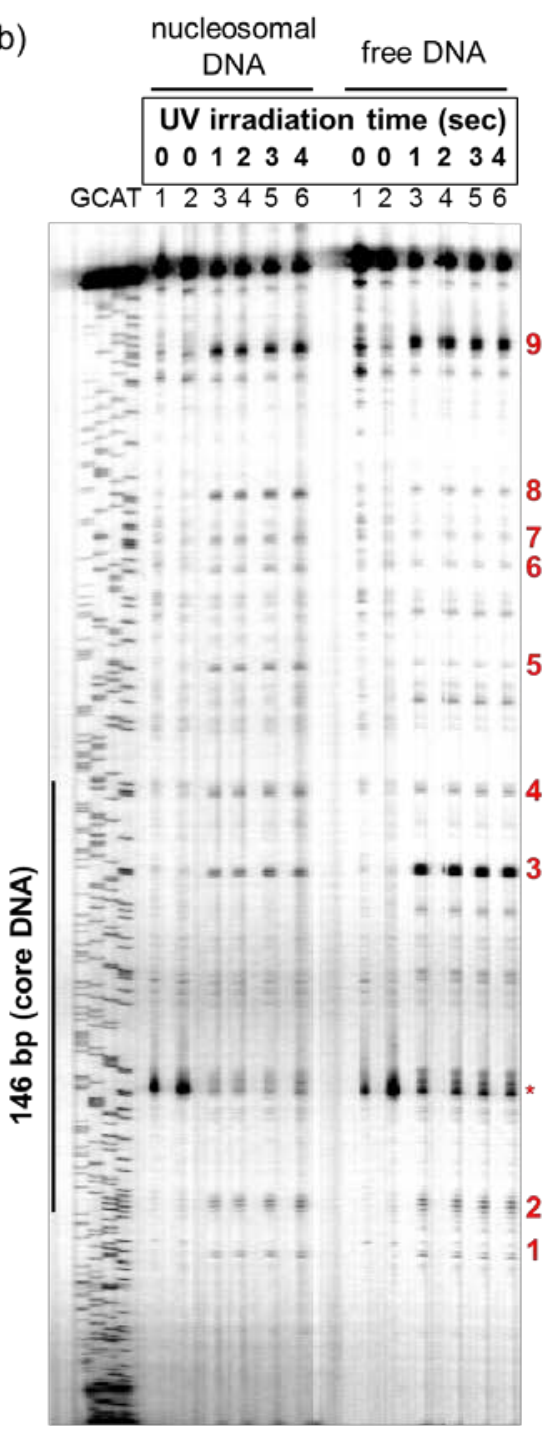

Figure 3. (a) Reconstitution of mononucleosome using 382 bp DNA containing 146 bp of Widom 601 sequence and histone octamer. (b) Analysis of DNA2 fragment by using 6\% denaturing gel electrophoresis. The DNA cleavage sites are marked from 1 to 9 . The band marked * derives from secondary structure of the DNA. (Lane 1) DNA only (Lanes 2-6) 365 nm irradiation for 0, 1, 2, 3, 4 seconds with $10 \mathrm{nM}$ DNA and $30 \mathrm{nM}$ Hoechst 33258. Photoreaction result on the nucleosome is shown on the left side, and the photoreaction result in free DNA is shown on the right side. (c) Mapping of DNA cleavage sites after photoreaction of DNA2 top strand (all Ts were replaced with ${ }^{\mathrm{Br}} \mathrm{Us}$ ). The cleavage sites are indicated by numbers (from 1 to 9). The underlined area in the DNA sequence indicates the 146 bp of core DNA. (d) Densitometric analysis of the cleavage bands in free DNA (top) and in nucleosomal DNA (bottom).

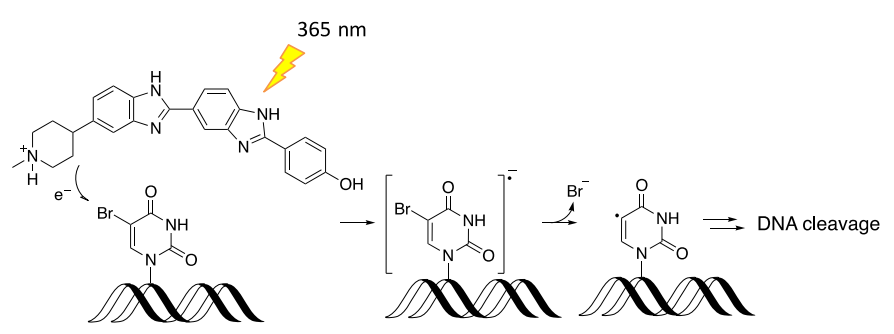

Figure 4. The suggested mechanism of DSB formation by UVA irradiation in the presence of Hoechst 33258.

\section{Conclusion}

In summary, we have demonstrated that DNA cleavages occur on ${ }^{B r}$ U-substituted DNA sensitized with Hoechst 33258 under UVA irradiation. DNA cleavage also occurred in nucleosomal DNA. These results suggest the following mechanism for DSB formation in UVA micro-irradiation: electron transfer from Hoechst 33258 to ${ }^{\text {Br}} U$ occurs to yield a uracil-5-yl radical (Fig. 4). In the absence of a hydrogen donor, the uracil-5-yl radical abstracts $\mathrm{C}^{\prime}$ ' hydrogen of the sugar moiety, this can cause singlestrand breaks and DSBs in the DNA.

\section{Acknowledgments}


We thank the Ministry of Education, Culture, Sports, Science and Technology in JAPAN (MEXT), administrated by Japan Society for the Promotion of Science for the financial support. Thanks to Prof. Dr. David Boykin and Prof. Dr. W. David Wilson (Georgia State University) for DB2120, DB2277 and discussions on these two compounds.

\section{References and notes}

1. Berns, M.W. Meth. Cell Biol., 1978, 18, 277-294

2. Cremer, C.; Cremer, T. Mutat. Res., 1986, 163, 33-40.

3. Bonner, W. M.; Redon, C. E.; Dickey, J. S.; Nakamura, A. J.; Sedelnikova, O. A.; Solier, S.; Pommier, Y. Nat. Rev. Cancer, 2008, 8, 957-967

4. Kinner, A.; Wu, W.; Staudt, C.; Iliakis, G. Nucleic Acids Res., 2008, 36, 5678-5694.

5. FitzGerald, J. E.; Grenon, M.; Lowndes, N. F. Biochem. Soc. Trans., 2009, 37, 897-904.

6. Misteli, T.; Soutoglou, E. Nat. Rev. Mol. Cell Biol., 2009,10,243254.

7. Stucki, M.; Jackson, S.P. DNA Repair, 2006, 5, 534-543.

8. Benjdia, A.; Heil, K.; Barends, T. R. M.; Carell, T.; Schlichting, I. Nucleic Acids Res., 2012, 40, 1-11

9. Fei, J.; Kaczmarek, N.; Luch, A.; Glas, A.; Carell, T.; Naegeli, H. PLoS Biol, 2011, 9, e1001183

10. Limoli, C. L.; Ward, J. F. Radiat. Res, 1993, 134, 160-169.

11. Suzuki, K.; Yamauchi, M.; Oka, Y.; Suzuki, M.; Yamashita, S. Nat. Protoc., 2011, 6, 134-139.

12. Walter, J.; Cremer, T.; Miyagawa, K.; Tashiro, S. J. Microsc., 2003, 209, 71-75.

13. Beishline, K.; Kelly, C. M.; Olofsson, B. A.; Koduri, S.; Emrich, J.; Greenberg, R. A.; Azizkhan-Clifford, J. Mol. Cell. Biol., 2012, 32, 3790-3799.

14. Harshman, K. D.; Dervan, P. B. Nucleic Acids Res., 1985, 13, 4825-4835.
15. Breusegem, S. Y.; Clegg, R. M.; Loontiens, F. G. J. Mol. Biol., 2002, 315, 1049-1061.

16. Hashiya, F.; Saha, A.; Kizaki, S.; Li, Y.; Sugiyama, H. Nucleic Acids Res., 2014, 42, 13469-13473.

17. Saha, A.; Kizaki, S.; De, D.; Endo, M.; Kim, K. K.; Sugiyama, H. Nucleic Acids Res., 2016, 44, e125.

18. Sugiyama, H.; Fujimoto, K.; Saito, I. Tetrahedron Lett., 1996, 37, 1805-1808.

19. Morinaga, H.; Takenaka, T.; Hashiya, F.; Kizaki, S.; Hashiya, K.; Bando, T.; Sugiyama, H. Nucleic Acids Res., 2013, 41, 4724-4728.

20. Sugiyama, H.; Tsutsumi, Y.; Fujimoto, K.; Saito, I. J. Am. Chem. Soc. 1993, 115, 4443-4448.

21. Paul, A.; Nanjunda, R.; Kumar, A.; Laughlin, S.; Nhili, R.; Depauw, S.; Deuser, S. S.; Chai, Y.; Chaudhary, A. S.; DavidCordonnier, M. H.; Boykin, D. W.; Wilson, W. D. Bioorg. Med. Chem. Lett., 2015, 25, 4927-32.

22. Harika, N. K.; Paul, A.; Stroeva, E.; Chai, Y.; Boykin, D. W. ; Germann, M.W.; Wilson. W. D. Nucleic Acids Res., 2016, 44, 4519-4527.

23. Kornberg, R. D.; Lorch, Y. Cell, 1999, 98, 285-294.

24. Vasudevan, D.; Chua, E. Y.; Davey, C. A. J. Mol. Biol., 2010, 403, 1-10.

25. Leslie, K. D., Fox, K. R. Biochemistry 2002, 41, 3484-3497.

26. Zou, T.; Kizaki, S.; Pandian, G. N.; Sugiyama, H. Chem. Eur. J. 2016, 22, 8756-8758.

27. Kizaki, S.; Zou, T.; Li, Y.; Han, Y. W.; Suzuki, Y.; Harada, Y.; Sugiyama, H. Chem. Eur. J. 2016, 22, 16598-16601.

\section{Supplementary Material}

Supplementary data associated with this article can be found, in the online version 


\section{Supplementary Information}

\section{UVA irradiation of ${ }^{\mathrm{B}} \mathrm{U}$-substituted DNA in the presence of Hoechst 33258}

Abhijit Saha, ${ }^{a,+}$ Seiichiro Kizaki, ${ }^{a,+}$ Ji Hoon Han, ${ }^{a}$ Zutao Yu, ${ }^{a}$ Hiroshi Sugiyama ${ }^{\star a, b}$

a Department of Science, Graduate School of Science, Kyoto University, Sakyo, Kyoto 6068501 (Japan)

${ }^{b}$ Institute for Integrated Cell-Material Sciences (iCeMS), Kyoto University, Yoshida Ushinomiya-cho, Sakyo, Kyoto 606-8502 (Japan)

$\left.{ }^{+}\right]$These authors contributed equally to this work.

* To whom correspondence should be addressed.

Tel: +81-75-753-4002; Fax: +81-75-753-3670; Email: hs@kuchem.kyoto-u.ac.jp 
Table S1. List of the DSB sites detected in DNA1 and DNA2 after analyzing both strands. The bottom-strand analysis of DNA2 is shown in Figure S4.

\begin{tabular}{|c|c|c|}
\hline DSB Sites & DNA1 & DNA2 \\
\hline $\begin{array}{l}5^{\prime}-\mathrm{A} A^{\mathrm{Br}} \mathrm{U}^{\mathrm{Br}} U-3^{\prime} \\
3^{\prime}-\mathrm{Br}^{\mathrm{Br}} \cup A A-5^{\prime}\end{array}$ & Site 1, 3, 4, 5 (high intensity) & Site 3 (high intensity) \\
\hline $\begin{array}{l}5^{\prime}-{ }^{\mathrm{Br}} \cup^{\mathrm{Br}} \cup A A-3^{\prime} \\
3^{\prime}-\mathrm{A} A^{\mathrm{Br}} \cup^{\mathrm{Br}} \cup-5^{\prime}\end{array}$ & Site 6 (moderate intensity) & - \\
\hline $\begin{array}{c}5^{\prime}-\mathrm{Br}^{-} \cup A^{\mathrm{Br}} \mathrm{B}^{\mathrm{Br}} \mathrm{U}-3^{\prime} \\
\text { 3'- }^{\mathrm{B}} \cup A A-5^{\prime}\end{array}$ & Site 7 (low intensity) & Site 1(low intensity) \\
\hline $\begin{array}{l}5^{\prime}-{ }^{B r} \cup A^{B r} \cup A-3^{\prime} \\
3^{\prime}-A^{B} \cup A^{B r} \cup-5^{\prime}\end{array}$ & - & Site 2 (low intensity) \\
\hline
\end{tabular}




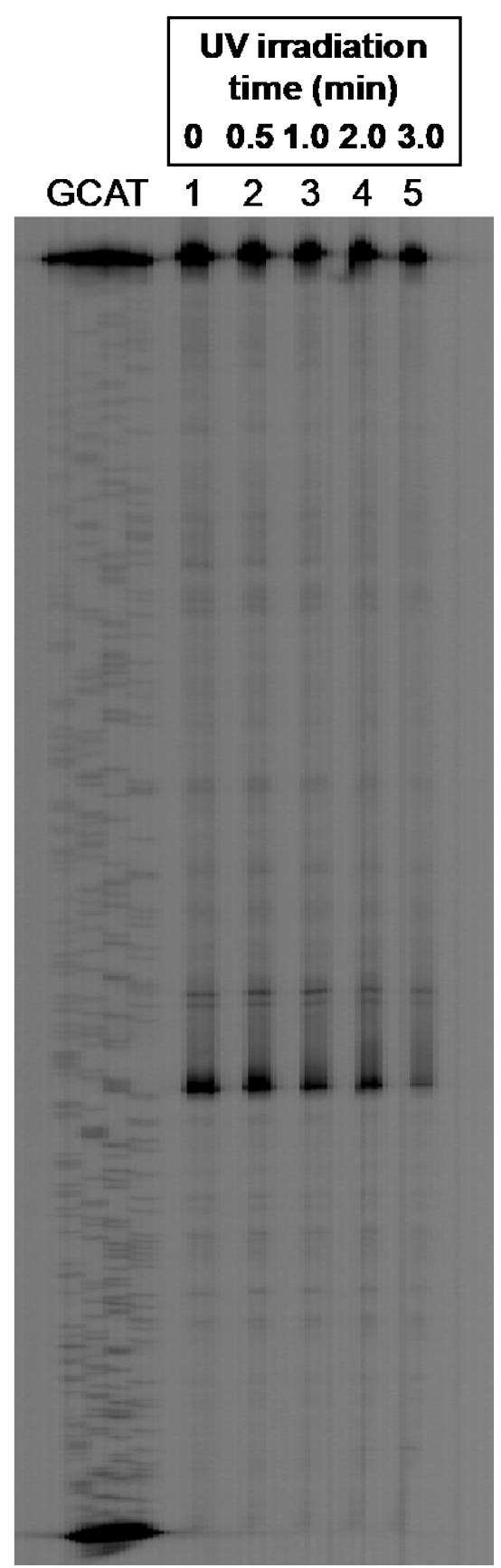

Figure S1. Photoreaction using DAPI on DNA2. The reaction mixture contains $10 \mathrm{nM}$ DNA and $1 \mu \mathrm{M}$ of DAPI. Irradiation was performed with $365 \mathrm{~nm}$ UV for 0-3 min. 


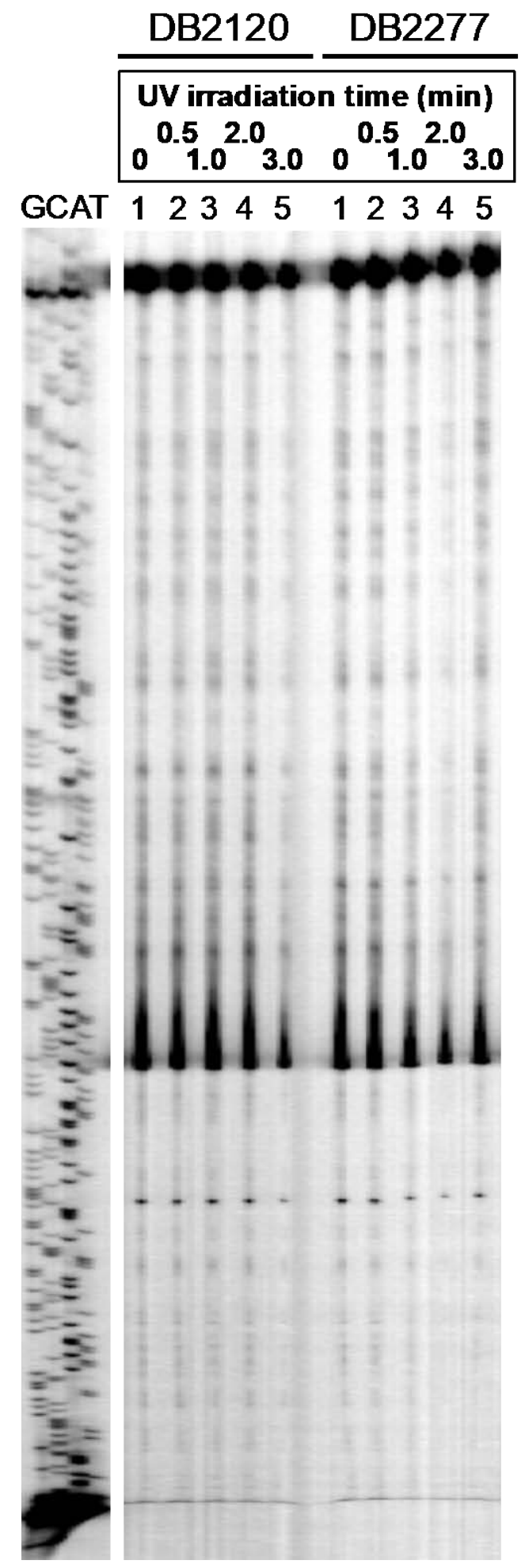

Figure S2. Photoreaction using DB2120 and DB2277 on DNA2 (bottom strand). The reaction mixture contains $10 \mathrm{nM}$ DNA and $1 \mu \mathrm{M}$ of DB2120 or DB2277. Irradiation was performed with $365 \mathrm{~nm}$ UV for 0-3 min. 


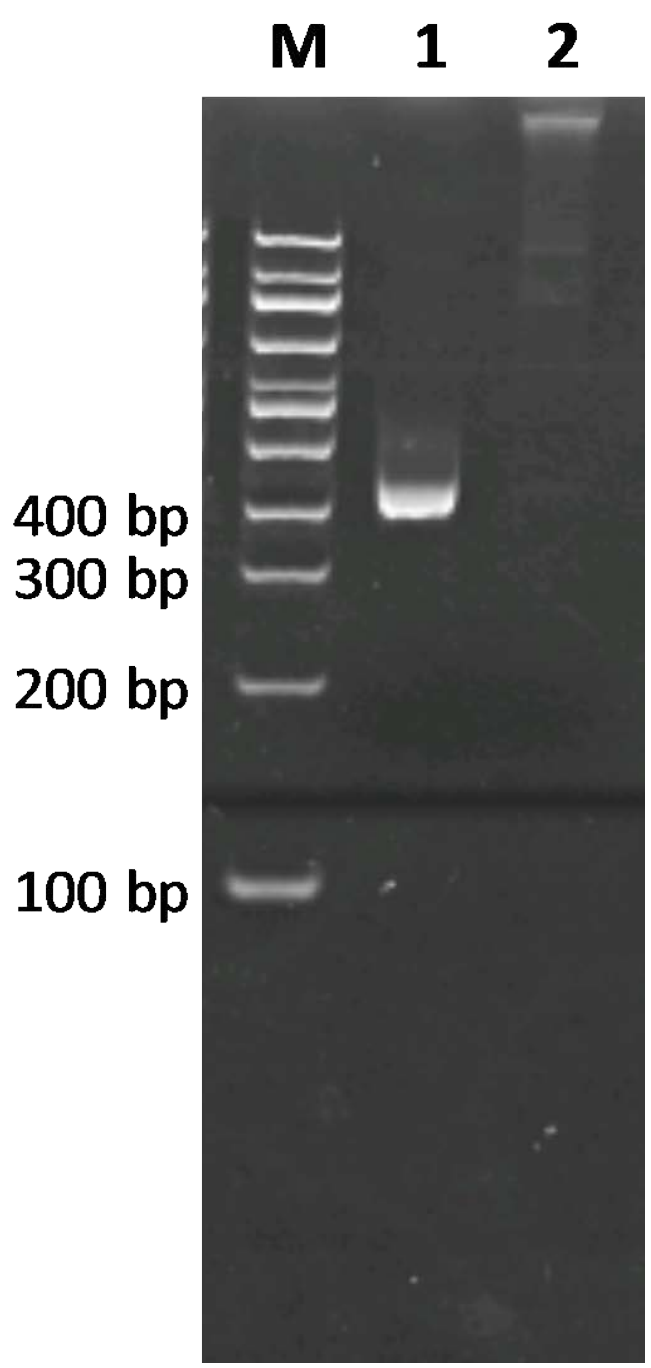

Figure S3. 6\% native polyacrylamide gel electrophoresis result of free DNA (lane1) and mononucleosome (lane 2), which was reconstituted using DNA2 (containing 146 bp of Widom 601 sequence) and histone octamer. 


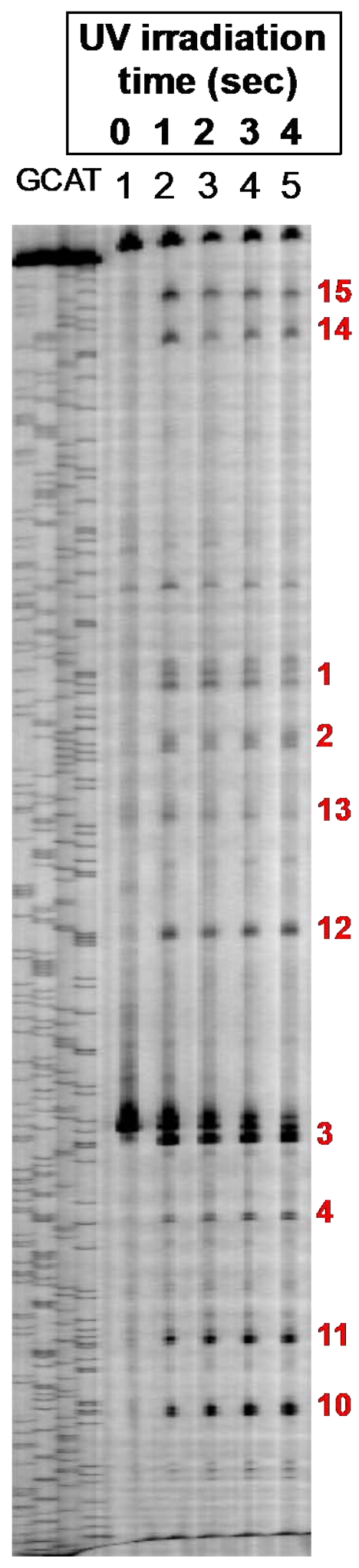

Figure S4. Shown the strand cleavage bands in the bottom strand of DNA2 after photoreaction. 